\title{
EFFICIENCY, PRODUCTIVITY AND RETURNS TO SCALE IN PORTS: A COMPARISON OF DATA ENVELOPMENT ANALYSIS AND ECONOMETRIC ESTIMATION WITH AN APPLICATION TO CARIBBEAN SMALL ISLAND DEVELOPING STATES
}

\author{
Shelly-Ann Julien, ${ }^{1}$ Jonathan Cowie $^{1}$ and Jason Monios ${ }^{2 *}$ \\ 1 Transport Research Institute, Edinburgh Napier University, Merchiston Campus, \\ Edinburgh, EH10 5DT, United Kingdom. \\ 2 Kedge Business School, Domaine de Luminy, Rue Antoine Bourdelle, 13009 Marseille, \\ France. orcid.org/0000-0002-4916-9718 \\ * Corresponding author. Email: jason.monios@kedgebs.com
}

\begin{abstract}
The paper investigates for the first time the evolutionary technical efficiency and productivity of ports in Small Island Developing States (SIDS). The focus is primarily on Caribbean SIDS, benchmarked against two comparator groups, major top ports and ports in other SIDS in the Pacific and Indian Oceans. Both a non-parametric DEA and the previously under-utilised econometric COLS Malmquist Productivity Index (MPI) model are used. The results reveal a significantly lower level of technical efficiency in the Caribbean when assessed against top ports, but higher when compared to other SIDS. Caribbean ports achieved a higher rate of productivity improvement compared to top ports, and thus partially closed the efficiency gap, but not as much as ports in other SIDS. This was primarily the result of higher returns to density due to the rising traffic levels of the latter group.
\end{abstract}

Analysis of both SIDS groups against the top group revealed that there exist 'two tiers' in terms of port development, with those in the first representing a level of efficiency that those in the second simply cannot match. In some respects therefore, this 'inefficiency' may be better described as port under-utilization. This suggests that, for these ports, maximizing the efficient use of existing capacities and only thereafter considering port expansion could be the most feasible option for improving technical efficiency in the medium to long-run.

Keywords: Port productivity; Port efficiency; Caribbean Ports; Small Island Developing States (SIDS); Malmquist Productivity Index; Data Envelopment Analysis (DEA); Corrected Ordinary Least Squares (COLS); Minimum Efficient Scale (MES) 


\section{Introduction}

Economic growth remains an objective of every nation, particularly for countries that are less economically developed such as Small Island Developing States (SIDS). According to the UNCTAD (2014a), one way to achieve wealth creation is by focusing attention on the challenges faced by transport and trade logistics. Given the unique characteristics of SIDS, notably high import content, insularity, geographic remoteness and small economies, all of these factors emphasize the importance of having "well-functioning, reliable, sustainable and resilient transportation systems, particularly the maritime sector for SIDS development and international trade survival" (UNCTAD, 2014b: 1). Such policies are consistent with "supply led" economic development, therefore the underlying theory is that economic growth will follow improvements in transport-related infrastructure (Cowie, 2010).

Broadly in line with these views, political organisations in SIDS regions, such as the Caribbean Community (CARICOM), have over the years committed to significantly improving their maritime sector, claiming that enhancing the sector has the potential to fuel CARICOM's trade, increase port productivity and generate significant cost savings (CARICOM, 2013). These claims underline the need for research in the area of port efficiency and productivity with regard to SIDS.

Consequently, this paper builds on recent research on port efficiency and productivity in Latin America and the Caribbean (LAC), by focusing on all Caribbean island ports, not just the larger ones, as well as including ports located in other SIDS in the Pacific and Indian Oceans as a comparator group. Importantly, the focus on SIDS includes smaller developing container ports, and as such highlights some of the issues that smaller ports present with regard to efficiency and productivity assessments. An additional aim of the research is to provide a comparative analysis of two different methods of Malmquist productivity estimation - the well-used data envelopment analysis (DEA) method and the overlooked econometric corrected ordinary least squares (COLS). The latter approach offers some attractive properties with regard to efficiency and productivity assessments; specifically, assessment is now based on a modelled production process rather than efficiency estimation, at the same time introducing statistical inference into the assessment. As such, this approach should complement existing literature on the topic.

We examine Caribbean ports by a three-way comparative analysis, with the comparators being ports in other SIDS and the world's top ports. Top ports represent an aspirational group for some Caribbean ports, for, given the importance of trade, such ports are considered as key to economic development in the region. This group is also most likely to define best practice and be at the forefront of development of port operations over time. The other SIDS ports, on the other hand, may be rather considered as a direct peer reference group. A list of all ports included in the study is given in Table 7 in Appendix 1. 


\section{The Caribbean Small Island Developing States}

The Caribbean consists of approximately 30 island states and 40 million inhabitants. Given its unique composition and geographic locality, situated along some of the main east - west and north - south shipping routes, the region's maritime industry and ports play an integral part in facilitating growing international trade (Wilmsmeier and Hoffman, 2008). As regards the main ports in the region, over the years there has been a clear shift in policy focus. Until recently, the general trend was to move away from gateway ports, toward more of a transhipment role, as in the case of Kingston, Jamaica and Freeport, Bahamas (Wilmsmeier et al 2014). Despite this policy shift, the level of transhipment traffic has nevertheless been diminishing, as this traffic has shifted more towards Panama and Cartagena, Colombia. At the same time, other smaller Caribbean countries have adopted progressive competitive port strategies in an attempt to create strong business identities of their own. A clear example being Caucedo's green port development in the Dominican Republic. This at a time when the introduction of larger vessels in global trunk routes has begun a process whereby vessels cascade down to secondary Latin American and Caribbean routes (Wilmsmeier, 2013), creating requirements for new infrastructure not only in the region's main ports but also in smaller ones. All of these issues raise important challenges, particularly regarding the quality and capacity of existing port and hinterland infrastructures which are briefly discuss below.

In line with these developments, the Caribbean's total container traffic has shown evidence of very strong growth in recent times, despite the adverse economic consequences of the real estate crisis that began in September 2008. In the seven years prior, TEU throughput more than doubled, growing at an average annual rate of over $12 \%$. This growth was partially slowed by the effects of the economic and financial downturn when, in one year alone (end2008 - end-2009), throughput saw a decline of 19.4\%, with further negative growth rates of $1.9 \%$ per annum throughout the period 2008-2011. Nevertheless, over the whole decade 2001-2011, Caribbean ports experienced a 5.6\% compound annual growth rate. A closer look at the region's trade reveals a similar trend, particularly for exports which grew by $9 \%$ p.a. over the same period, despite a single year fall in 2009 of $37 \%$. This result indicates a very strong link between container traffic and the region's economic growth (see Figure 1 and Table 1).

FIGURE 1 HERE

TABLE 1 HERE

Ports situated in the more developed countries of the region notably The Bahamas, Jamaica, Dominican Republic and Trinidad and Tobago, accounted for approximately 85\% of traffic 
across the whole period, and hence also the majority of growth that occurred. Actual growth rates however were fairly consistent for ports across the whole region, irrespective of port size, although there are obviously variations within that broad perspective (see Figure 2).

\section{FIGURE 2 HERE}

In an attempt to improve the operations of these ports, the Inter-American Development Bank (IADB) has over the years provided trade related assistance, in the form of disbursements for the improvement of port infrastructure and operations. Over the period 2002 to 2009, these progressively increased year-by-year, from 98.1 million USD to 422.4 million USD (Caricom, 2013). Today, the region continues to expand the operations of its ports in order to accommodate more traffic, particularly in light of the completion of Panama's canal expansion. Major development initiatives recently completed, ongoing, and proposed, continue to reinforce the importance of port efficiency improvement. ${ }^{1}$

\section{Past Research on Port Efficiency, Productivity and Scale Effects}

A list of earlier studies on port efficiency and productivity is presented in Table 8 in Appendix 2, although space limitations prevent a full review of this very large body of research. Efficiency studies have tended to adopt a multi-port and often multi-country approach, primarily using panel data, and in the main have employed data envelopment analysis (DEA) as the method to estimate efficiency, with a few using the stochastic frontier analysis (SFA) method. Indeed, of the 52 studies examined by Merkel and Holmgren (2017), 38 used DEA, 13 used SFA and one employed both methods. As examples, Itoh (2002) used DEA window analysis to estimate the efficiencies of eight Japanese ports during 1990-1999. Inputs were specified as the number of container berths, number of cranes, area of container terminal and labour; the output variable was TEU throughput. Cullinane et al (2005) analysed the world's top 30 ports in 1999 to investigate the influence of port ownership on efficiency. The authors used two variants of the basic DEA Constant Returns to Scale (CRS) and Variable Returns to Scale (VRS) models, with TEU throughput chosen as the output, and total quay length, terminal area, number of gantry cranes, number of yard gantry cranes and number of straddle carriers as the inputs. Coto-Millán et al (2017) estimated a stochastic frontier function for Spanish ports over the period 1986 to 2012 using five different output measures and labour, capital and support services as inputs.

\footnotetext{
${ }^{1}$ These range from major expansions at large hubs such as Freeport, Bahamas to upgrades at smaller ports such as St. John's, Antigua \& Barbuda, and Kingstown, St. Vincent (Caribbean Development Bank, 2016).
} 
Port related productivity studies on the other hand have almost universally applied DEA estimated efficiencies to derive Malmquist Productivity Index (MPI) measures. For example, Al-Eraqi et al (2009) applied such a framework to investigate 22 Middle East and East African terminals, finding an annual average improvement in Total Factor Productivity (TFP) of $1.8 \%$ p.a., with most of this improvement being driven by Technical Change (TC). Similarly, DíazHernández et al (2008) analysed the impact of regulatory reform on the productivity of Spanish ports, again using DEA derived MPI measures. They found an annual 2\% TFP improvement over the four year period reviewed, in spite of the failure in the reforms to eradicate inefficiencies. The one exception to this approach is Barros (2005), who examined technical change and technical efficiency using the SFA approach. This work however was not defined within the MPI framework, and may be more accurately described as an analysis of cost changes over time rather than technical change per se.

In recent port efficiency and productivity studies pertaining to Latin America and the Caribbean (LAC), with inclusion of the major Caribbean ports, Wilmsmeier et al (2013) analyzed the evolution of container terminal productivity and efficiency of 20 terminals in LAC and Spain in the period 2005-2011. Their analysis employed a DEA based MPI, finding a net $3 \%$ gain across the whole period reviewed, with no difference found in the efficiencies of Spanish and LAC ports. In a later study, Serebrisky et al (2016) estimated the efficiencies of 63 LAC ports, again only including the major ports in the Caribbean, and used panel data over the period 1999 to 2009 to estimate a stochastic frontier model (SFA). Results revealed an improvement in the average efficiency of ports, from $52 \%$ to $64 \%$, with an overall average of $59 \%$. Interestingly, the time variable was found to be small and statistically insignificant, suggesting that all productivity improvement was the result of efficiency change rather than technical progress. Finally, Suarez-Aleman et al (2016) investigated regional differences in developing countries' ports. Included in their analysis were 64 ports in LAC, in the period 2000-2010. The region's average technical efficiency stood at $58 \%$, with results of the MPI revealing an average of a $2.2 \%$ cumulative growth in productivity. Surprisingly, but consistent with the findings of Serebrisky et al (2016), virtually all of this increase was the result of efficiency rather than technical change, which suggests most increases in productivity were the result of the eradication of inefficiencies rather than the development of operations technology.

Whilt the port efficiency literature is extensive, scale effects in port operations is a considerably under-researched area, with only three dedicated studies on the subject. Based on a sample of 24 container terminals located in 10 Korean ports, Seo and Park (2016) examined scale effects, based on a single year estimation (2013). Their results suggested a Minimum Efficient Scale (MES) point between 717k and 753k TEU per annum, with perhaps a surprisingly sizeable number of terminals found to be operating above the MES point. Chang et al (2012), from a survey of cost data collected from a combination of Korean container terminals and shipping lines, found a U-shaped Long Run Average Cost (LRAC) curve, with an 
MES point at 650,000 TEU per year. Finally, Vanelslander (2007), cited in Kaselimi et al (2011), examined port cost structures and how these evolved over time, and through the estimation of a short run average cost curve found a far lower MES point of around 150k TEUs.

\section{Port Efficiency and Productivity Assessment}

Technical efficiency is the simple case of an evaluation of the output to inputs ratio, with firms defined as efficient where this ratio is maximized at a particular point in time. This position then represents the benchmark of best production practice against which the performance of other firms is evaluated. As such, efficiency is a short run state of affairs, for what is considered to be 'efficient' will change from one year to the next. Productivity on the other hand evaluates how that performance evolves over time; being thus an absolute measure of the long run. As regards micro data, the Malmquist Productivity Index (MPI) has become the standard approach to productivity estimation. The formulations of Caves et al (1982) and Färe et al (1994) are the two most commonly applied MPI measures to estimate total factor productivity change (TFP). Temporal changes in productivity can be attributed to two key sources of the management and business environment, namely i) catch up effects, referred to as efficiency change, and ii) frontier shift effects, known as technical change. Often overlooked in studies, technical change shifts the production possibility frontier, moving best practice outwards, thus creating adverse efficiency change, i.e. inefficiency, to the companies found below and to the left of the frontier. Under normal circumstances, one would expect these inefficiencies be removed over time, hence the idea of the catch-up effect.

As can be seen in our literature review, by far the most commonly applied method in the port sector to estimate efficiencies is DEA, with some studies using SFA exclusively for efficiency assessments. In our case, both the DEA and COLS approaches are applied to the estimation of efficiency and assessment of productivity.

\subsection{Data Envelopment Analysis Efficiency and Productivity Assessment}

The theoretical exposition of DEA efficiency estimation has been well outlined in this journal (see for example Schøyen \& Odeck, 2013) and other texts (for example Coelli et al., 2005), therefore it is not repeated here. In this context, all productivity estimations are determined from CRS generated efficiency estimates, with VRS efficiency estimates added to derive scale estimates.

As regards productivity, following Färe et al (1994), total factor productivity change between two years, $s$ and $t$, is given by: 


$$
M_{o}\left(y^{s}, x^{s}, y^{t}, x^{t}\right)=\frac{d_{o}^{t}\left(y^{t}, x^{t}\right)}{d_{o}^{s}\left(y^{s}, x^{s}\right)}\left[\frac{d_{o}^{s}\left(y^{t}, x^{t}\right)}{d_{o}^{t}\left(y^{t}, x^{t}\right)} \times \frac{d_{o}^{s}\left(y^{s}, x^{s}\right)}{d_{o}^{t}\left(y^{s}, x^{s}\right)}\right]^{1 / 2}
$$

As such, the DEA approach reduces the problem to the estimation of four efficiency measures, namely production in year $s$ to the frontier in year $s$, production in year $t$ to the frontier in year $t$, production in year $s$ to the frontier in year $t$ and finally production in year $t$ to the frontier in year $s$.

Efficiency change is thus given by:

$$
E C=\frac{d_{o}^{t}\left(y^{t}, x^{t}\right)}{d_{o}^{s}\left(y^{s}, x^{s}\right)}
$$

which represents the relative distance to the efficiency frontier for the two years under comparison. Technical change is given by:

$$
T C=\left[\frac{d_{o}^{s}\left(y^{t}, x^{t}\right)}{d_{o}^{t}\left(y^{t}, x^{t}\right)} \times \frac{d_{o}^{s}\left(y^{s}, x^{s}\right)}{d_{o}^{t}\left(y^{s}, x^{s}\right)}\right]^{1 / 2}
$$

which represents the geometric mean of two cross frontier comparisons, to establish the extent to which production technology has progressed from one year to the next.

Therefore, for the individual firm $k$ :

$$
\mathrm{TFP}_{\mathrm{k}}=\mathrm{EC}_{\mathrm{k}} \times \mathrm{TC}_{\mathrm{k}}
$$

\subsection{Corrected Ordinary Least Squares (COLS) Efficiency and Productivity Assessment}

Key to efficiency estimation under the COLS approach is to specify the functional relationship between the output and the inputs:

$$
Q=f(X)
$$

The nature of the relationship between the output and the inputs, as well as between the inputs themselves, needs to be formally defined. In this case, the Translog specification is the one most consistent with the key underpinning economic principles of returns to scale and factor substitutability (Greene, 2017), and in the general case is specified as: 


$$
\ln Q_{i}=a+\sum_{i=1}^{n} b_{i} \ln X_{i}+\sum_{i=1}^{n} c_{i} \frac{1}{2}\left(\ln X_{i}\right)^{2}+\sum_{i=1}^{n} \sum_{j=1}^{n} d_{i j} \ln X_{i} \ln X_{j} \quad ; i \neq j
$$

In the current context, the problem of port efficiency is specified in terms of output as our dependent variable (annual TEU throughput), and total berth length, total equipment and total area as our inputs (independent variables). In the general translog specification, and adding a time variable, this gives:

$$
\begin{aligned}
\ln T E U_{i k}=a & +b_{B} \ln B L_{i k}+b_{A} \ln T A_{i k}+b_{E} \ln T E_{i k}+c_{B B} \frac{1}{2}\left(\ln B L_{i k}\right)^{2} \\
& +c_{A A} \frac{1}{2}\left(\ln T A_{i k}\right)^{2}+c_{E E} \frac{1}{2}\left(\ln T E_{i k}\right)^{2}+c_{B A} \ln B L_{i k} \ln T A_{i k} \\
& +c_{B E} \ln B L_{i k} \ln T E_{i k}+c_{A E} \ln T A_{i k} \ln T E_{i k}+g_{t} t_{k}+g_{t t} \frac{1}{2} t_{k}^{2} \\
& +h_{t B} t_{k} \ln B L_{i k}+h_{t A} t_{k} \ln T A_{i k}+h_{t E} t_{k} \operatorname{lnT} E_{i k}+e_{i k}
\end{aligned}
$$

As the translog assumes variable returns to scale, for productivity assessment the assumption of CRS needs to be imposed with the special case of unitary scale returns, therefore the following constraints are applied:

$$
\begin{aligned}
& b_{B}+b_{A}+b_{E}=1 \\
& c_{B B}+c_{B A}+c_{B E}=0 \\
& c_{A A}+c_{B A}+c_{A E}=0 \\
& c_{E E}+c_{B E}+c_{A E}=0 \\
& h_{t B}+h_{t A}+h_{t E}=0
\end{aligned}
$$

With $e^{+}$defined as the largest positive residual, efficiency in the current year $t$ is given by:

$$
\operatorname{Effy}_{i T T}=\exp \left(e_{i t}-e^{+}\right)
$$

And in the previous years as:

$$
\text { Effy } y_{i S S}=\exp \left(e_{i s}-e^{+}\right)
$$

Thus efficiency change is:

$$
E C_{i t}=\frac{E f f y_{i T T}}{E f f y_{i S S}}
$$


Technical change is calculated as an average (geometric mean) of the rate of change of output with respect to time in years $t$ and $s$, hence the geometric mean of:

$$
T C_{i t}=\frac{\mathrm{d} T E U_{i t}}{d t}=g_{t}+g_{t t} t_{t}+h_{t B} \operatorname{Ln}\left(B L_{i t}\right)+h_{t A} \operatorname{Ln}\left(T A_{i t}\right)+h_{t E} \operatorname{Ln}\left(T E_{i t}\right)
$$

And:

$$
T C_{i s}=\frac{\mathrm{d} T E U_{\mathrm{is}}}{d t}=g_{t}+g_{t t} t_{s}+h_{t B} \operatorname{Ln}\left(B L_{i s}\right)+h_{t A} \operatorname{Ln}\left(T A_{i s}\right)+h_{t E} \operatorname{Ln}\left(T E_{i s}\right)
$$

Hence:

$$
T C_{i s t}=\text { Geomean }\left(T C_{i t}, T C_{i s}\right)
$$

And for completeness, TFP (change) is again given by:

$$
T F P_{i t}=E C_{i t} \times T C_{i s t}
$$

\section{Data}

Data at the port level was collected from Containerisation International Yearbooks, for the period 2001 to 2011 (see for example Containerisation International, 2007) and as such this aggregation of terminal data is consistent with the bulk of the research literature on the subject (see for example Serebrisky et al., 2016 or De Oliveira and Cariou, 2015). After data compilation and cleaning, the total sample size consisted of 65 seaports over the 11-year timespan. Of these, 49 were defined as top ports (ranked by container throughput in 2011), thus used as a benchmark. The remaining 16 ports are located in SIDS (as defined by UNCTAD, 2014b), with 12 of them in the Caribbean and 4 in the Pacific and Indian oceans (labelled Other Small Island Developing States, OSIDS). In order to ensure that the top ports represented a meaningful benchmark to the Caribbean ports, and as part of the data cleaning process, partial productivity measures were calculated, and ports which produced very high values were removed from the sample. The criterion used was to ensure a continuous distribution in partial productivities, which occurred at around \pm 2 standard deviations from the mean. This approach resulted in the removal of all ports with a high percentage of transshipment traffic, thus, as smaller Caribbean ports have predominately gateway traffic, this method ensured they were only compared against ports with similar types of container traffic flows. As regards the second benchmarking group, ports in OSIDS, unsurprisingly transshipment traffic was not found to be an issue.

As shown in Table 8 in Appendix 2, TEU throughput has become the most widely used and accepted indicator of port output when measuring technical port efficiency. Furthermore, this 
measure is the chief basis upon which container ports are compared, particularly when assessing their relative size, investment magnitude, activity levels and port production (Cullinane and Wang, 2006).

The factors of production (land, labour and capital) are key input factors, but, as shown in Table 8, there is some variety in the inputs chosen in previous port studies, with the vast majority only including capital factors. Our research follows on from these studies by specifying terminal area $(\mathrm{h})$, berth length $(\mathrm{m})$, and total terminal equipment (consisting of ship to shore-, yard gantry- and straddle carriers) as the factor inputs. Due to a lack of data, however, a labour variable was not included, which must be recognized as an important shortcoming. However, Cullinane and Wang (2006) state that while the omission of labour can lead to considerable fluctuations in port efficiency estimates over time, i.e. in the short run, the use of panel data tends to offset such effects. This approach results in reliable estimates of a port's underlying productivity trend in the long run and suggests that the specified inputs capture most of the (long run) variation in output. Although, as stated, short run (efficiency) deviations around that may be understated due to the absence of a labour variable.

Descriptive statistics according to each of the four port groups are presented in Table 2. What the table shows is a very broad range in terms of port sizes included in the study. Also shown in the last two columns are the annual average (cumulative) growth rates over the period, for both throughput and a simple average of the inputs. These trends show a sector in rapid development, with an overall average growth rate of just under $13 \%$ per annum. Furthermore, it also suggests considerable improvements in port productivity, as the inputs grew at lower rates than throughput levels. As regards the Caribbean, the rate of growth of the sector was considerably below that of top ports, but significantly higher than that found in OSIDS. To a certain extent, therefore, both the Caribbean and OSIDS still lag behind in the development of container traffic.

\section{TABLE 2 HERE}

Partially masked by the averages presented in Table 2, there nevertheless exists a high level of variability in the scale of port operations in the Caribbean region, more so than any of the other groupings shown. In some respects, ports in the Caribbean roughly split into major and minor, with the major ports far more consistent with the scale of operations in the top group, 
and minor ports more consistent with the OSIDS group ${ }^{2}$. This distinction is important in the current context, as the main focus of the paper is the impact of investment on efficiency and productivity across the whole region, not just the major ports.

\section{Results}

\subsection{Efficiency analysis}

Presented first are the econometric estimations of the translog production function under the assumptions of CRS and VRS. These are shown in Table 3.

\section{TABLE 3 HERE}

With high $\bar{R}^{2}$ values, both models fit the data well, and to some extent corroborate the views of Cullinane and Wang (2006) with regard to the absence of a labour input. In both specifications, most of the parameters are in the expected direction and statistically significant. One point of concern is the negative estimate attached to the singular total equipment variable; however in both cases when estimated the marginal product was found in the vast majority of cases to be positive. One point of interest is to statistically evaluate which of the two specifications is more appropriate with regard to overall specification. The log ratio likelihood test was thus applied and found to be statistically significant, indicating that when estimating scale effects, the VRS model is more appropriate to use.

For the DEA efficiencies, the Data Envelopment Analysis Program (DEAP) Version 2 software, developed by Tim Coelli (1996) was used. Table 4 presents efficiency estimates for both methods, shown as annual averages for the whole sample and each group.

\section{TABLE 4 HERE}

In a way, examining efficiency results is of limited value, as the main point of interest, namely how these evolve over time, comes out in the productivity analysis. Nevertheless, both the

\footnotetext{
${ }^{2}$ Indeed an earlier draft did formally spilt the Caribbean ports into these two groups, however it was found that this division made little difference to the main conclusions of the research.
} 
DEA and COLS derived estimates show only limited variations over the whole period, although the latter suggests for the whole sample a more consistent overall profile than the DEA. Port level estimates are found to be highly correlated $(r=0.9012)$. Interestingly however, and perhaps of more relevance, the two methods do not correlate at the aggregated level $(r=$ 0.1490 ), which would suggest the results produce inconsistencies in summarized form. What is missing of course is the issue of technical change, as the way this is predicted to evolve over time will have a considerable impact on efficiency levels. The other major difference is in the magnitude of the estimates at the general level of efficiency, with DEA producing far higher values. This is a known issue with DEA (see for example Odeck, 2007), as it attempts to maximize the efficiency score, so where ports have an overprovision of one or more of the factor inputs, the weight of these in the efficiency calculation will be minimized (even to the point of zero). Nevertheless, the econometric estimation confirms that all inputs have a significant influence on the output, and thus all should be considered. Within the sector however, for smaller ports a high level of technical inefficiency would seem to be almost inevitable, as the size and availability of port facilities will largely be driven by demand side factors, but a minimum level of handling facilities are required to meet the lowest levels of demand. In the efficiency assessment however, these ports are being compared against others that in some cases have facilities in operation 24/7 supported by highly effective land side operations, which in terms of intensity of operation few ports can attain. In some respects therefore, this 'inefficiency' is probably better described as port under-utilization. This issue is more clearly brought out in the distribution of the COLS efficiencies shown in Figure 3.

\section{FIGURE 3 HERE}

Figure 3 shows a very pronounced skew to the left, underlining that, in the terms specified, very few ports could be described as 'efficient'. Also added to the figure is the cumulative frequency distribution, which shows that less than $20 \%$ of ports in the sample had a computed efficiency score of $60 \%$ or more. It should be stressed that this efficiency estimation is based on the CRS assumption, but nevertheless represents a very unusual efficiency profile, particularly as it includes 49 of the 100 largest container ports in the world. What this finding suggests is that there exist 'two tiers' in terms of port development, with those in the first representing a level of efficiency that those in the second simply cannot match. As a 
consequence, the true underlying level of 'inefficiency' in one sense may be considerably over stated, thus reinforcing the idea above of port under-utilisation ${ }^{3}$.

The issue of port under-utilisation is particularly relevant in the case of the majority of ports in the Caribbean and OSIDS regions, where facilities remain idle for long periods of time, yet these ports are compared against the largest and most intensively worked ports in the world; therefore a substantial efficiency 'gap' is found. What becomes more important therefore from an analytical perspective is how this efficiency difference has evolved over time. In the case of the Caribbean, the difference has remained fairly static, thus suggesting that the efficiency of these ports evolved at around the same level as those in the top group. Ports in the OSIDS comparator group however have experienced a substantial improvement of over $9 \%$ according to DEA and 7\% according to COLS. Initially this increase in efficiency suggests that these ports have been successful in partially closing the efficiency gap whereas those in the Caribbean have not. Reasons as to why this may be the case are more fully examined in the productivity analysis below.

\subsection{Productivity analysis}

Results from the calculation of the Malmquist productivity indices for both DEA and COLS assessments are presented in Table 5. The table gives an annual summary and then the overall averages, broken down by group for the period analysed, with these figures plotted as cumulative aggregates in Figures $4 a \& 4 b$.

\section{TABLE 5 HERE}

\section{FIGURE 4 HERE}

Figure 4a presents the results relating to overall TFP, showing an extremely high level of consistency between the two methods, far higher than was expected. Under both assessments, all TFP gains in the medium to longer term have been driven by Technical

\footnotetext{
${ }^{3}$ One apparent way to overcome this skewness is through estimation of a Stochastic Frontier, which does produce results more consistent with the DEA figures, i.e. in the range of 55\%/60\% averages (Serebrisky et al 2016 and confirmed by our own unreported analysis). Coincidently, this result probably in many respects is a better reflection of the 'true' level of efficiency, in that given the demand conditions facing many ports, this level represents an optimum value that can be achieved when being compared against the most productive. The stochastic variable however tends to model away this important characteristic of the substantial differences in the sheer intensity and form of these operations.
} 
Change (TC) rather than Efficiency Change (EC), with average annual productivity gains between $1.5 \%-2.2 \%$ per annum. Two reasons exist for this high level of consistency. Firstly, the extensive data cleaning exercise would have ensured a very high degree of reliability in the raw data. Secondly, this is a sector that has experienced considerable growth over the period, and such strong underlying trends will almost inevitably produce greater consistency in estimation methods.

Where major differences do occur is in how this TFP improvement evolves over time with regard to EC and TC. Whilst the overall averages for the whole period produce consistent values, the DEA estimates tend to produce greater inconsistencies over the course of the period, in which TC is characterised by two years of strong growth, but also four years of decline, whilst EC has tended to rise and then fall. The reality is that in a mature industry, such as the container sector, technical change is a long progressive development, rather than occurring in short bursts. The COLS results tend to better reflect this fact, with TC generally rising over the period under examination, but then tailing off as a consequence of the effects of the economic downturn. EC then represents short run variations around that long-term trend, and whilst TC clearly defines the underlying trend of TFP, EC dictates the overall pattern of that TFP development over the period.

The results in Table 5 are broken down by comparator group in Table 6 .

TABLE 6 HERE

As stated, in a mature industry, all TFP should be driven by TC rather than EC, which is generally reflected in both sets of results in table 6 . This finding also underlines the fact that positive TC creates inefficiencies, as the 'best practice' production frontier is expanded. Subsequent periods should see the eradication of these inefficiencies. This may not be the case however at the regional level, as the sector in different regions will evolve at different rates, thus some productivity gains may be as a result of the 'catch up' effect, in other words EC. This appears to be the case for the Caribbean and OSIDS areas, and in both cases has led to stronger productivity growth than in top ports. In many respects, this growth will be associated with demand conditions, in that rising container traffic over time, at smaller ports such as those found in parts of these regions, has led to economies of density rather than economies of scale. In other words, most of the gains are simply due to better utilization of the existing infrastructure rather than through the synergy effects of port expansion.

\subsection{MES and Returns to Scale}


In the current context, the issue of the minimum efficiency scale (MES) and the general issue of scale effects is an important consideration, as the majority of ports in the Caribbean tend to be small in size and thus may be expected to have potential gains in productivity through such effects. The question remains however, as to the extent of these potential gains.

Both the DEA and COLS approaches to efficiency and productivity assessments allow the issue of returns to scale (RTS) to be examined. In the case of DEA, the assessment is relatively straightforward: as the level of scale inefficiency is known, regardless if this relates to increasing or decreasing returns, scale inefficiency can be plotted against output and any patterns between port size and scale inefficiency identified. For the mid-point year of 2006, the result is shown in Figure 5.

\section{FIGURE 5 HERE}

Figure 5 outlines a very clear pattern of declining levels of scale inefficiency, in the area of increasing returns to scale, as the level of TEUs rise. This general trend continues up to the scale efficient point, followed by rising levels of scale inefficiency in the area of decreasing returns to scale. This is best represented by a regression line of logarithmic form, which is consistent with the theoretical long run production function in neo classical economics. Overall the regression line of best fit produces an $R^{2}$ value of 0.7652 , meaning that just over $76 \%$ of the variation in scale inefficiency can be 'explained' by the variation in throughput. When the intersection point is calculated on the example year, the MES point is found to lie at just over 780K TEU per annum.

The econometric estimation of returns to scale is expressed as the rate of change of output with respect to the rate of change of the inputs, being the summation of the marginal products, which in this case is given by:

$$
R T S_{i k}=M P_{B L i k}+M P_{T A i k}+M P_{T E i k}
$$

Where:

$$
\begin{aligned}
& M P_{B L i k}=\partial T E U_{i k} / \partial B L_{i k}=b_{B}+c_{B B} \ln B L_{i k}+c_{B A} \ln T A_{i k}+c_{B E} \ln T E_{i k}+h_{t B} t_{k} \\
& M P_{T A i k}=\partial T E U_{i k} / \partial T A_{i k}=b_{A}+c_{A A} \operatorname{LnT} A_{i k}+c_{B A} \ln B L_{i k}+c_{A E} \ln T E_{i k}+h_{t A} t_{k}
\end{aligned}
$$




$$
M P_{T E i k}=\partial T E U_{i k} / \partial T E_{i k}=b_{E}+c_{E E} \ln T E_{i k}+c_{B E} \ln B L_{i k}+c_{A E} \ln T A_{i k}+h_{t E} t_{k}
$$

The same as above, and to avoid unnecessary clutter, the results relating to the mid-point year (2006) are shown in Figure 6.

\author{
FIGURE 6 HERE
}

This result shows the same general pattern as the DEA results in terms of overall profile, and again it is consistent with neo classical production theory. The two sets of results are highly correlated; when the level of DEA scale inefficiency is correlated with the econometric RTS indicator, the analysis returns an $r$ value of 0.8818 . The main difference is in the size of these effects, which is not taken into consideration in the correlation coefficient. Under the econometric estimation for the example year, the MES point is found to lie at a throughput of just over $1.2 \mathrm{~m}$ TEU per annum, significantly higher than the DEA estimate. This finding is also significantly higher than previous authors have estimated and raises an important topic for future research, especially given the paucity of publications on this topic discussed earlier.

Under both assessments, most ports in the Caribbean (and in OSIDS) were found to be operating considerably under the MES point, in fact in most cases traffic levels could treble in size and the port would still experience increasing returns. As a consequence, the potential for further productivity gains through economies of density as a result of rising TEU levels appear to be far from being exhausted.

\title{
7. Closing discussion, conclusions and policy recommendations
}

While a small number of papers have examined the larger Caribbean ports, as part of an assessment of port efficiency and productivity in LAC, this paper has focused only upon Caribbean ports, in their role as SIDS, and included all those in the region with a container terminal. Two different approaches to the assessment of efficiency and productivity were applied, the well-used DEA approach and the less applied econometric COLS method, with the efficiencies and productivities of the Caribbean ports benchmarked against the performance of top ports and those located in other SIDS.

As regards application of the methods, the results reflect the known issue of higher estimates being produced by DEA. However, this characteristic appears to be particularly amplified in the port sector due to considerable differences in the intensity of operations between the 
major and minor ports. This ranges from $24 / 7$ operation through to large periods of nonproductive activity. To some degree, this inactivity can be overlooked in the DEA assessment through the adjustment of input weights. Consistencies in results tended to be variable. Whilst the results for overall TFP change were found to be highly correlated, at a level that far exceeded priors, efficiency summaries based on the annual means were found to be statistically insignificant. This finding was mainly due to differences in the pattern of how productivity gains were apportioned between efficiency change and technical change over the period. The COLS method modelled technical change as a long run evolving concept that was the prime driver of productivity improvement, with efficiency change representing short run fluctuations around that trend. This was in contrast to the more variable estimates of TC and EC produced by DEA, which exhibited a far less structured evolution of both concepts. In the wider context, the division between TC and EC and how this evolves over time is an important issue, as policy implications attached to declining productivity, due to a slow rate of TC (e.g. invest in better facilities, training, education), are very different to declines attributed to adverse EC (e.g. increase competitive pressures and other measures to reduce $x$-inefficiency).

As regards the productivity of Caribbean ports, due to the heavy influence of scale, to a large extent port efficiency is dependent upon market conditions, in particular the underlining strength of demand. With shipping trends towards larger vessels and transhipment ports, however, there remains some scope for the influence of policy on the commercial development of ports, either in their own right or as key secondary hubs. In this area policy appears to have had some limited success in improving and developing port efficiency in the Caribbean, clearly evidenced by the higher TFP growth experienced by this group of ports compared to the top group.

An efficiency gap remains, however, with even some evidence that towards the end of the period that this gap was potentially widening again. Combined with the results relating to potential scale gains (through density effects), these findings corroborate recent work by Sánchez (2017) which suggests that continued trade stagnation in the region does not warrant the level of port upgrades that have recently been undertaken. Caribbean ports were found to be operating far below MES, thus the potential for scale gains through density effects remain considerable.

\section{Acknowledgements}

The authors would like to thank both anonymous reviewers for their detailed comments and suggestions which strengthened the paper considerably. Any errors or omissions that remain are entirely the responsibility of the authors. 


\section{References}

Al-Eraqi, A., Khader, A. and Mustafa, A. (2009). DEA Malmquist Index Measurement in Middle East and East African Containers Terminals. International Journal of Shipping and Transport Logistics 1(3): 249-59.

Banker, R.D., Charnes, W.W and A. W. Cooper (1984). Some Models for Estimating Technical and Scale Efficiency in Data Envelopment Analysis, Management Science, 39(1): 1078 - 1092.

Barros, C. (2005). Decomposing Growth in Portuguese Seaports: a frontier approach. Maritime Economics and Logistics, 7: 297-315.

Barros, C., and Athanassiou. M. (2004). Efficiency in European sea ports with DEA: Evidence from Greece and Portugal. Maritime Economics \& Logistics, 6: 122-140.

Bo, L.U. and Wang, X.L. (2012). Comparative Studies on Efficiency Evaluation of Chinese and Korean Major Container Terminals. Advances in Information Sciences \& Service Sciences, 4: 434-442.

Caribbean Development Bank (2016). Transforming the Caribbean Port Services Industry: Towards the Efficiency Frontier. St Michael, Barbados: Caribbean Development Bank.

CARICOM, (2013). Caribbean Community Regional Aid for Trade Strategy 2013-2015, Georgetown, Guyana: CARICOM.

Caves D.C., Christensen, L.R., and Dievert, W.E. (1982). The economic theory of index number and the measurement of input, output, and productivity. Econometrica, 50: 1393-1414.

Chang, Y-T, Tongzon, J., Luo, M. and Lee, P. (2012). Estimation of optimal handling capacity of a container port: an economic approach, Transport Reviews, 32(2): $241-258$.

Charnes, A., Cooper W.W., and Rhodes, E. (1978). Measuring the efficiency of decision making units. European Journal of Operational Research, 2 (6): $429-444$.

Coelli, T. J. (1996). A Guide to DEAP version 2.1: Data Envelopment Analysis (Computer) Program, Working Paper 8/96, Department of Econometrics, the University of New England, Armidale Australia. 
Coelli, T., Prasada Rao, D., O'Donnell, C. and Battese, G. (2005). An introduction to efficiency and productivity analysis. New York: Springer Science + Business Media

Containerisation International (2007). Containerisation International Yearbook 2007. London: Informa Maritime \& Transport.

Coto-Millán, P., Fernández, X., Hidalgo, S. and Pesquera, M. (2017). Public regulation and technical efficiency in the Spanish port authorities, Transport Policy, 47: 139 - 148.

Cowie, J. (2010). The economics of transport: a theoretical and applied perspective. London: Routledge.

Cullinane, K., Ji, P., Wang, T. (2005). The relationship between privatization and DEA estimates of efficiency in the container port industry. Journal of Economics and Business, 57 (5): 433462.

Cullinane K., and Wang T-F. (2006). The efficiency of European container ports: A crosssectional data envelopment analysis, International Journal of Logistics Research and Applications, 9 (1): 19-31.

Dan, L.I., Weixin, L.U.A.N. and Feng, P.I.A.N. (2013). The Efficiency Measurement of Coastal Container Terminals in China. Journal of Transportation Systems Engineering and Information Technology, 13: 10-15.

De Oliveira, G. F. and Cariou, P. (2015). The impact of competition on container port (in)efficiency. Transportation Research Part A, 78: 124-133.

Díaz-Hernández, J.J., Martínez-Budría, E., and Jara-Díaz, S. (2008). Productivity in Cargo Handling in Spanish Ports during a Period of Regulatory Reforms. Networks and Spatial Economics, 8(2-3): 287-295.

Ding, Z-Y., Jo, J., Wang, Y. and Yeo, G-T. (2015). The relative efficiency of container terminals in small and medium sized ports in Chini. The Asian Journal of Shipping and Logistics, 31 (2): $231-251$

Färe R, Grosskopf S, Norris, M. and Zhongyong, Z. 1994. Productivity growth, technical progress and efficiency change in industrialised countries. The American Economic Review. 84(1): $66-83$. 
Greene, W. (2017). Econometric Analysis. New Jersey: Prentice Hall

Hung, S-H., Lu, W.M. and Wang, T.P. (2010). Benchmarking the Operating Efficiency of Asia Container Ports. European Journal of Operational Research 203(3): 706-13.

Itoh H. (2002). Efficiency Changes at Major Container Ports in Japan: A Window Application of Data Envelopment Analysis. Review of Urban and Regional Development Studies 14 (2): 133-152.

Kaselimi E. N, Notteboom, T. E., Pallis, A. A., Farrell, S. (2011). Minimum Efficient Scale (MES) and preferred scale of container terminals, Research in Transportation Economics, 32: 71 80.

Merkel, A. and Holmgren, J. (2017). Dredging the depths of knowledge: efficiency analysis in the maritime port sector. Transport Policy, 60: 63- 74 .

Niavis, S. and Tsekeris, T. (2012). Ranking and causes of inefficiency of container seaports in South-Eastern Europe. European Transport Research Review, 4 (4): 235-244.

Odeck, J. (2007). Measuring technical efficiency and productivity growth: a comparison of SFA and DEA on Norwegian grain production data. Applied Economics, 39: 2617 - 2630, DOI: $10.1080 / 00036840600722224$.

Sánchez, R. J. (2017). Caribbean container port catchment areas: 1998-2016 evolution and the risk of over-investment. Port Economics discussion paper 08/2017. Available at: http://www.porteconomics.eu/2017/08/28/portreport-caribbean-container-portcatchment-areas-1998-2016-evolution-and-the-risk-of-over-investment/ Accessed $3^{\text {rd }}$ June 2018. 
Schøyen, H. \& Odeck, J. (2013). The technical efficiency of Norwegian container ports: A comparison to some Nordic and UK container ports using Data Envelopment Analysis (DEA). Maritime Economics and Logistics. Volume 15 (2):, 197-221.

Seo, Y-J. and Park, J.S. (2016). The estimation of minimum efficient scale of the port industry. Transport Policy, 49: $168-175$.

Serebrisky T., Morales Sarriera, J., Suárez-Alemán, A., Araya, G., Briceño-Garmendía, C., Schwartz, J. (2016). Exploring the drivers of port efficiency in Latin America and the Caribbean. Transport Policy, 45: 31-45.

Suárez-Alemán, A., Sarriera J.M., Serebrisky T., Trujillo L. (2016). When it comes to container port efficiency, are all developing regions equal? Transportation Research Part A, 86: 56-77.

Tongzon, J. (2001). Efficiency measurement of selected Australian and other international ports using data envelopment analysis. Transportation Research Part A 35 (2): 107-122.

Turner. H., Windle. R., and Dresner. M. (2004). North American container port productivity: 1984-1997, Transportation Research Part E: Logistics and Transportation Review, 40(4): 339356.

UNCTAD (2014a). Closing the distance: Partnerships for resilience and sustainable transport systems in SIDS. Geneva: UNCTAD.

UNCTAD (2014b). Small island developing States: Challenges in transport and trade logistics. Geneva: UNACTD.

Valentine, V. F. \& Gray, R. (2001). The measurement of port efficiency using data envelopment analysis. Paper presented at the $9^{\text {th }}$ World Conference on Transport Research, June 2001, Seoul, South Korea, and available on line at: https://www.researchgate.net/profile/Vincent Valentine2/publication/277617009 The me 
asurement of port efficiency using data envelopment analysis/links/56e971ef08aecf036 b315beb.pdf, last accessed $14^{\text {th }}$ October 2018.

Vanelslander, T. (2007). Economies of scale in sea-port container handling: up to what level? In P. Hilferink (Ed.), Proceedings of the BIVEC-GIBET Transport Research Day (pp. 348 - 369).

Wang, T., and Cullinane, K. (2006). The Efficiency of European Container Terminals and Implications for Supply Chain Management. Maritime Economics \& Logistics, 2006 (8): 8299.

Wanke P.F. (2011). Determinants of Efficiency at Major Brazilian Port Terminals. Transport Reviews, 31 (5): 653-677.

Wilmsmeier, G. (2013). Liner Shipping Markets, Networks and Strategies. The implications for port development on the West Coast of South America. The case of Chile. ITF, Discussion Paper No 2013-22, November 2013.

Wilmsmeier, G., Hoffman, J. (2008). Liner Shipping Connectivity and Port Infrastructure as Determinants of Freight Rates in the Caribbean. Maritime Economics and Logistics. 10 (1-2): $130-151$.

Wilmsmeier G., Monios, J., Perez-Salas G. (2014). Port System Evolution- the case of Latin America and the Caribbean, Journal of Transport Geography, 39: 208-221.

Wilmsmeier G., Tovar, B., Sanchez R.J. (2013). The evolution of container terminal productivity and efficiency under changing economic environments. Research in Transportation Business \& Management, 8: 50-66.

World Bank. (2014). World DataBank World Development Indicators: Exports (US\$ Million), Statistics. Available at: https://data.worldbank.org/indicator Accessed December, 2016.

Wu, Y. and Goh, M., 2010, 'Container port efficiency in emerging and more advanced 
markets', Transportation Research Part E: Logistics and Transportation Review, 46 (6): 10301042. 
Appendix 1

TABLE 7 HERE 
Appendix 2

TABLE 8 HERE 
Figure 1. Caribbean Islands Container Port Traffic and Exports (US\$ Million) (2001-2011)

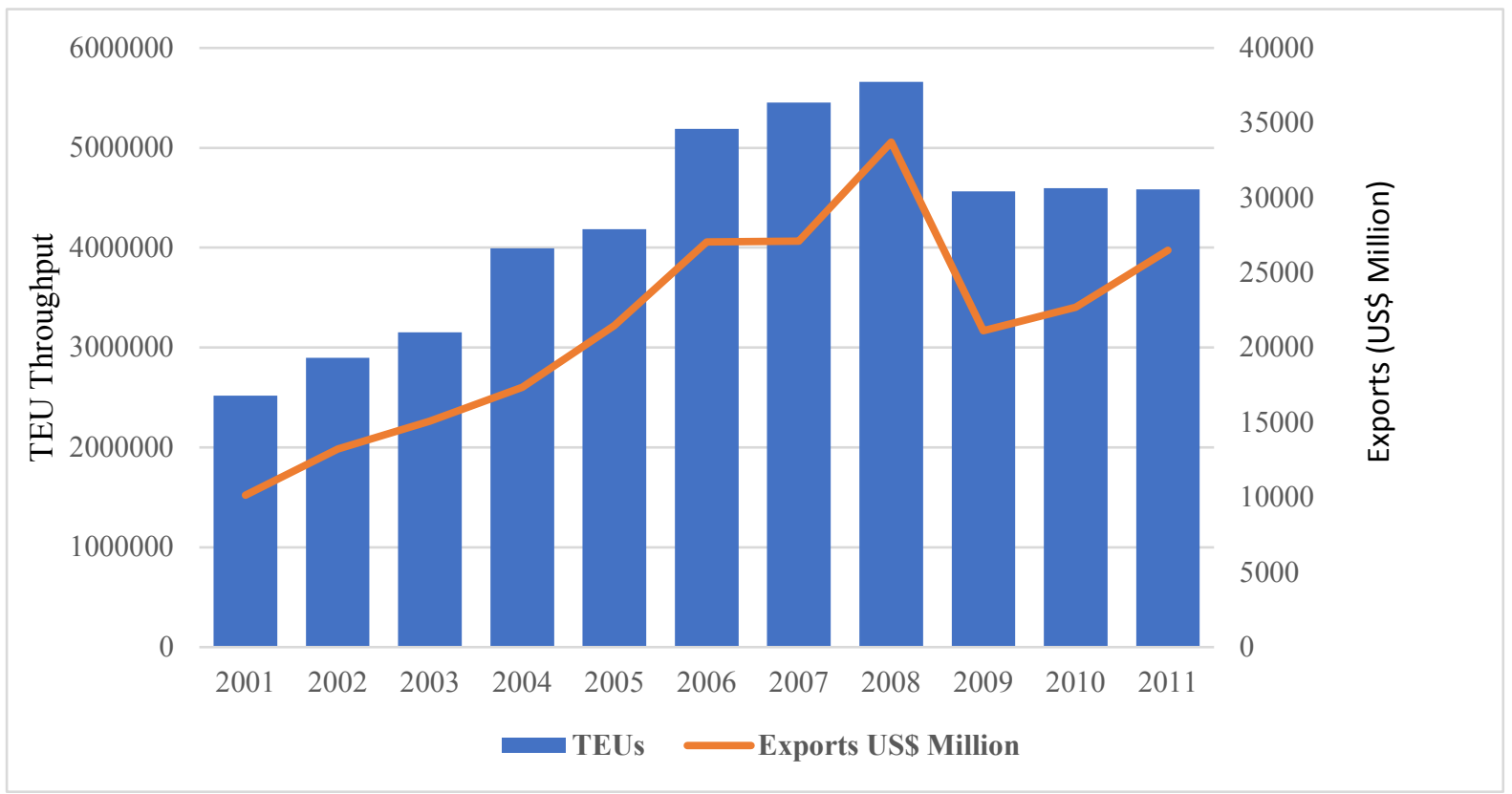

Source: Data compiled from Containerisation International Yearbooks (2000-2012), The World Bank (2014) 
Figure 2. Container Port Traffic Contribution per port (2001-2011)

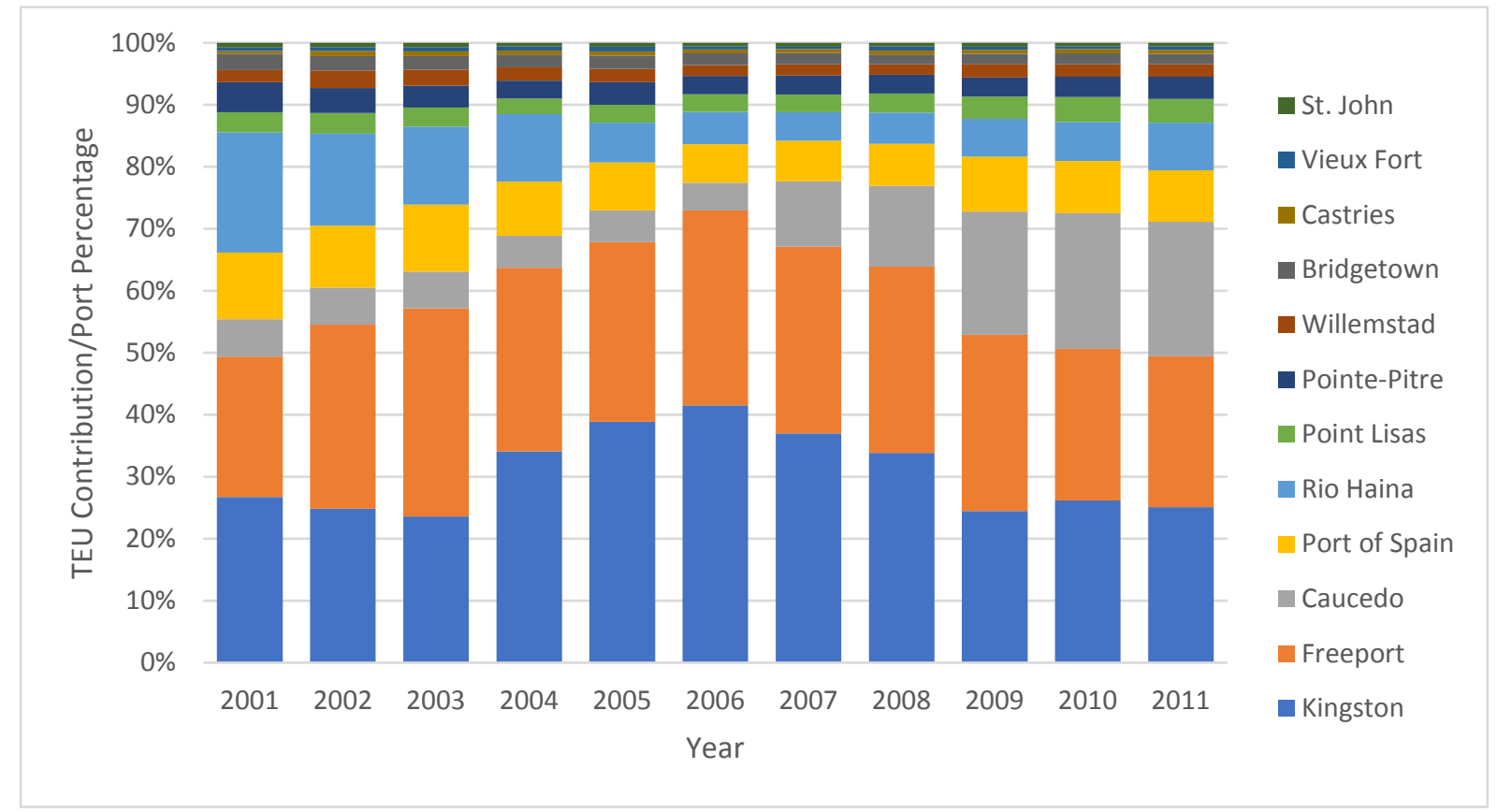

Source: Drawn from data contained in the Containerisation International Yearbooks (20002012) 
Figure 3: COLS Translog CRS Full Panel, Container Ports, Technical Efficiencies Distribution Whole Sample Period

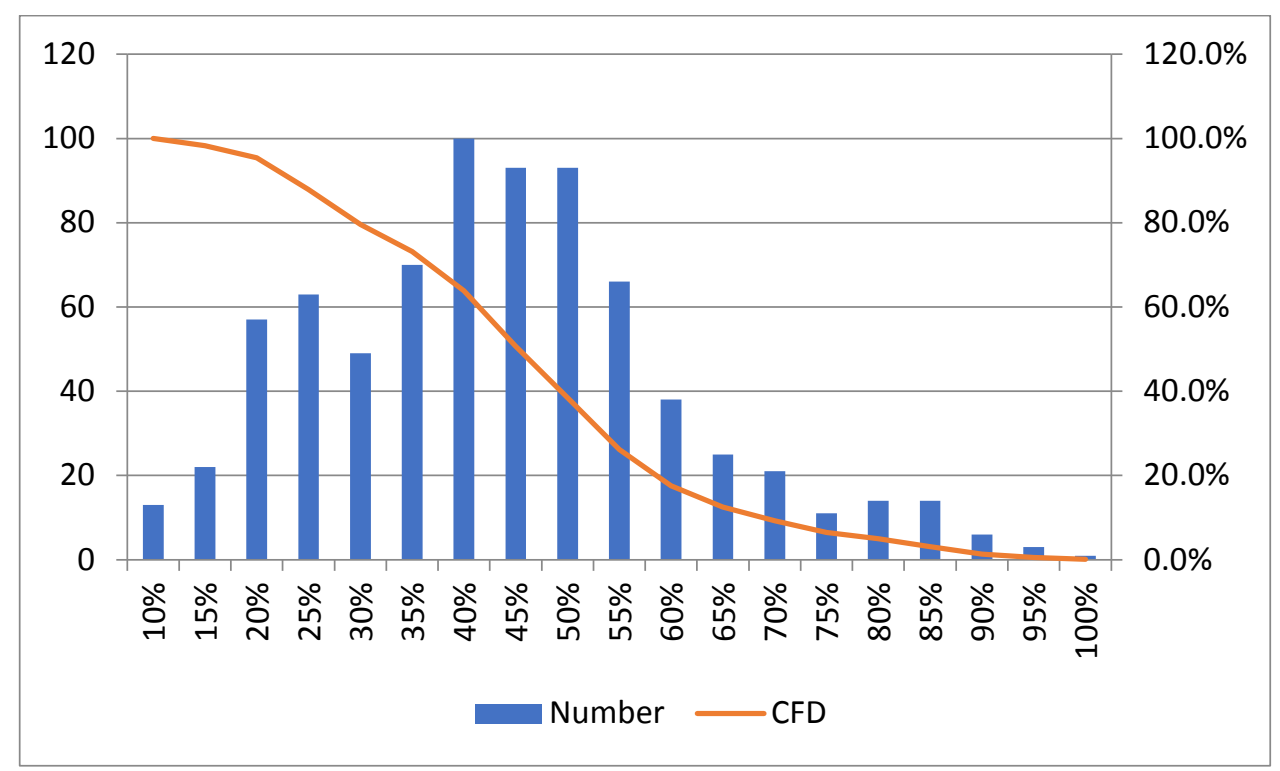


Figures $4 a \& 4 b$ : Total factor productivity, efficiency and technical change, cumulative values, whole sample, DEA and COLS estimates.

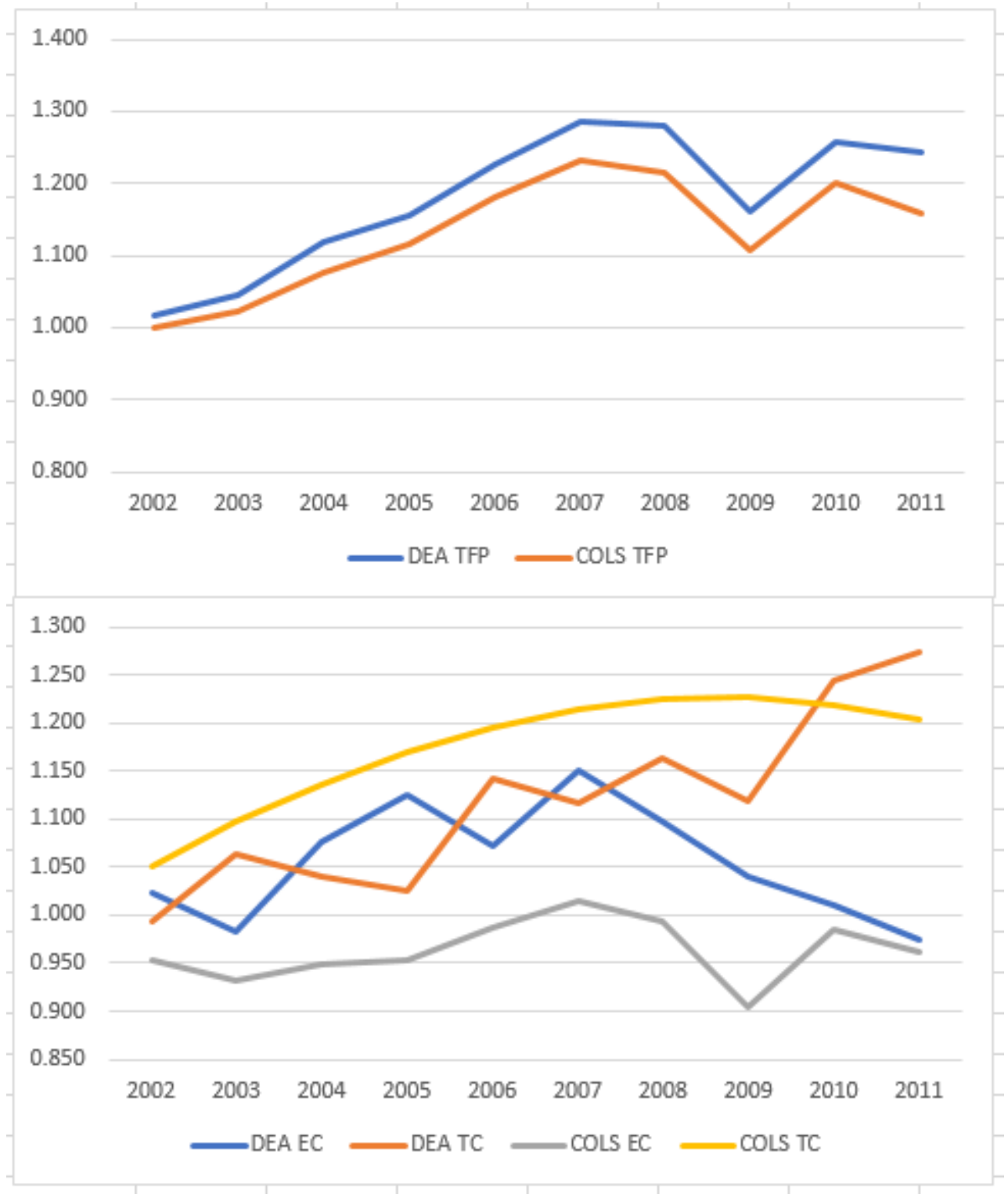


Figure 5: Scale Inefficiency (IRS \& DRS) against output (TEUs)

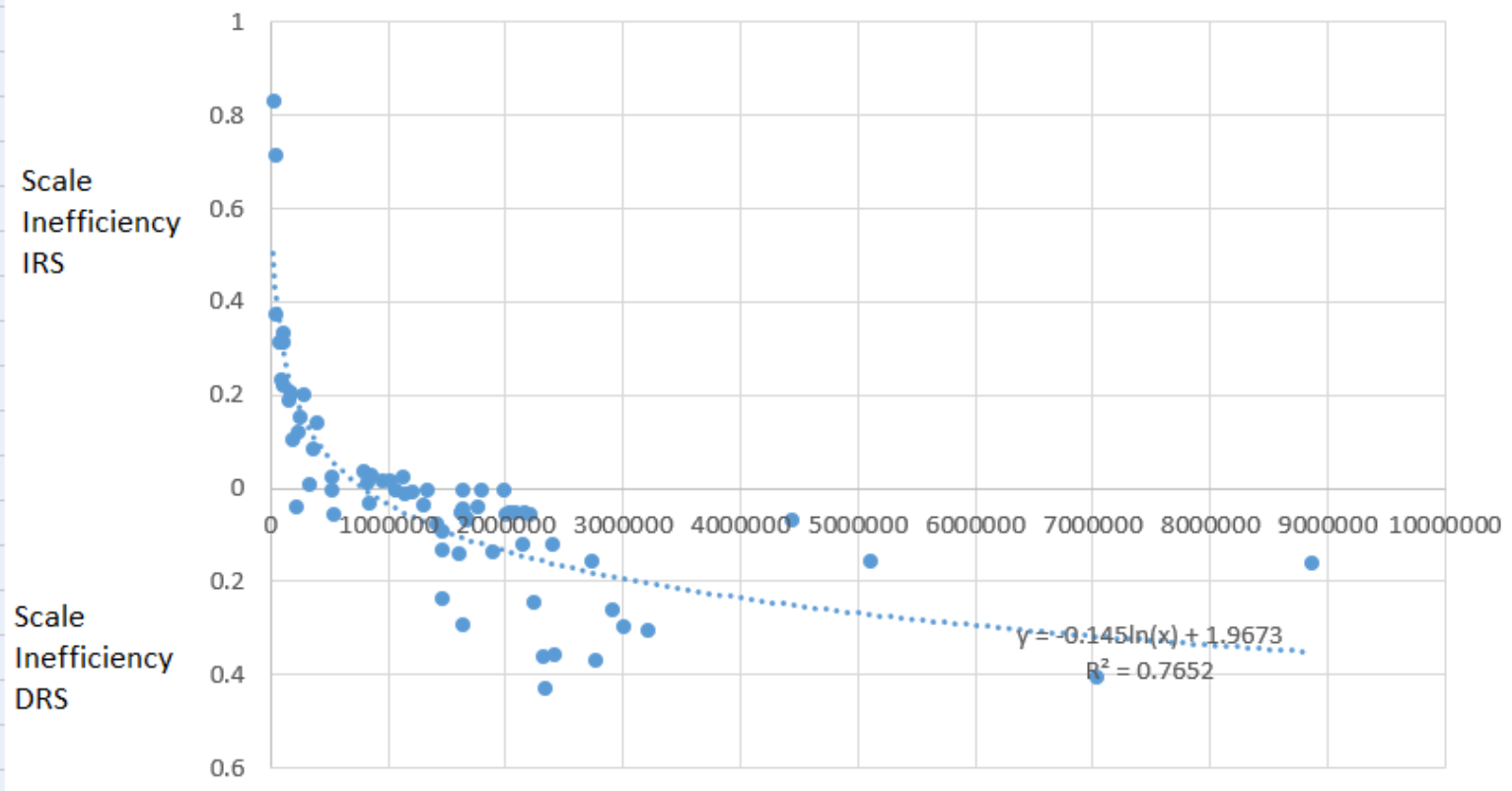


Figure 6: Scale effects, econometric estimation

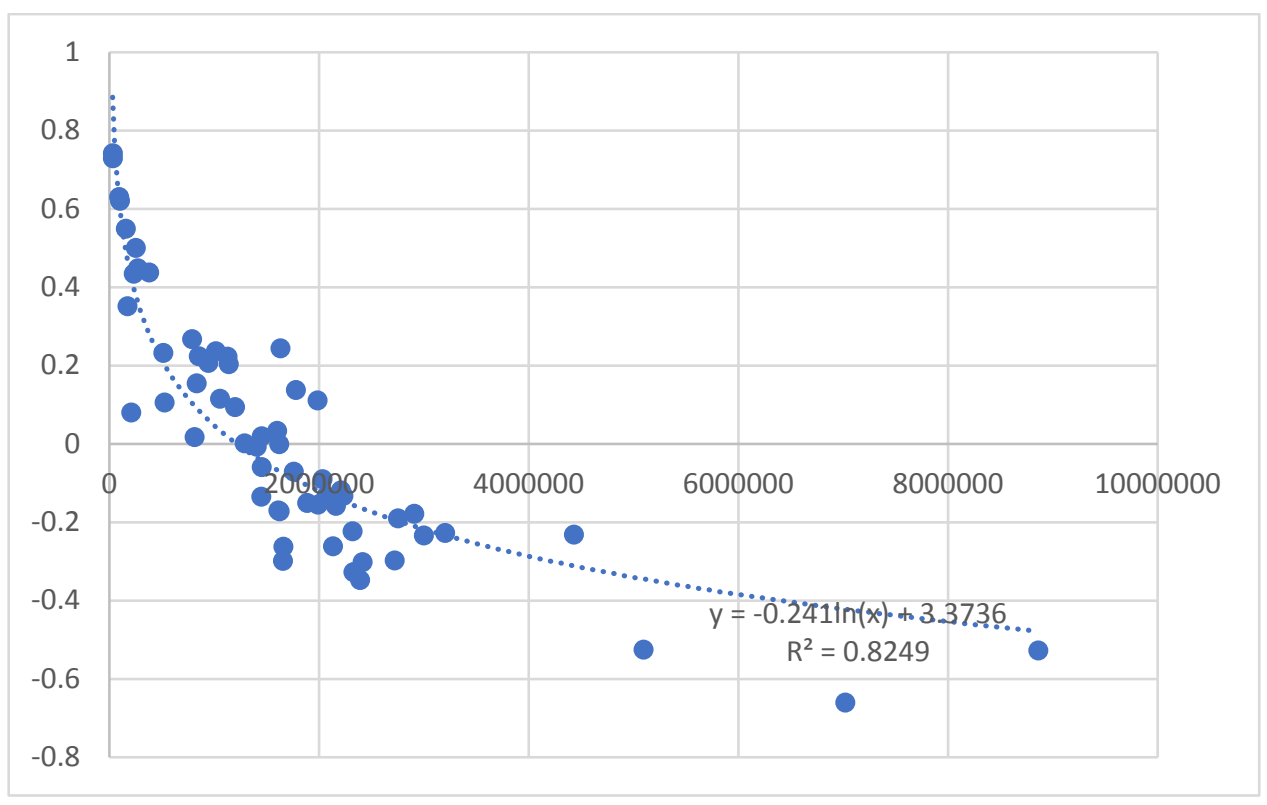


Table 1. Container Port Traffic Growth/ (Exports (US\$M)) (2001-2011)

\begin{tabular}{cc}
\hline Compound Annual Growth Rate (CAGR) \% \\
\hline $2001-2008$ & $7.6(11.5)$ \\
$2008-2011$ & $-1.9(-2.2)$ \\
$2001-2011$ & $5.6(9.1)$ \\
Growth Rate 2008-2009 & $-19.4(-37.3)$
\end{tabular}

Source: Authors' calculations; Data compiled from the Containerization International Yearbooks, 2000-2012, The World Bank, 2014 
Table 2. Descriptive statistics, averages per group (2001-2011)

\begin{tabular}{|c|c|c|c|c|c|c|c|c|}
\hline Group & $\begin{array}{l}\text { No. of } \\
\text { ports }\end{array}$ & Statistic & $\begin{array}{c}\text { Annual } \\
\text { throughput } \\
\text { (TEU) }\end{array}$ & $\begin{array}{l}\text { Berth } \\
\text { length } \\
(\mathrm{m})\end{array}$ & $\begin{array}{l}\text { Terminal } \\
\text { area }(\mathrm{h})\end{array}$ & $\begin{array}{c}\text { Terminal } \\
\text { equipment }\end{array}$ & $\begin{array}{c}\text { Throughput } \\
\text { Growth }\end{array}$ & $\begin{array}{l}\text { Input } \\
\text { Growth }\end{array}$ \\
\hline \multirow{3}{*}{ Top } & \multirow{3}{*}{49} & Average & $1,861,872$ & 3817 & 168 & 26 & $13.7 \%$ & $9.9 \%$ \\
\hline & & Minimum & 150,592 & 441 & 12 & 3 & $-5.7 \%$ & $-1.8 \%$ \\
\hline & & Maximum & $9,890,000$ & 15,130 & 765 & 104 & $218.9 \%$ & $157.0 \%$ \\
\hline \multirow{3}{*}{ CARI } & \multirow{3}{*}{12} & Average & 327,221 & 797 & 26 & 6 & $11.1 \%$ & $7.1 \%$ \\
\hline & & Minimum & 9554 & 210 & 3 & 1 & $-2.8 \%$ & $0.4 \%$ \\
\hline & & Maximum & $1,983,072$ & 2485 & 132 & 20 & $55.4 \%$ & $20.1 \%$ \\
\hline \multirow{3}{*}{ OSIDS } & \multirow{3}{*}{4} & Average & 148,841 & 772 & 26 & 3 & $7.2 \%$ & $2.4 \%$ \\
\hline & & Minimum & 54,862 & 450 & 8 & 2 & $0.4 \%$ & $1.0 \%$ \\
\hline & & Maximum & 454,433 & 1319 & 70 & 6 & $17.1 \%$ & $5.5 \%$ \\
\hline \multirow{3}{*}{ TOTAL } & \multirow{3}{*}{65} & Average & $1,420,758$ & 2960 & 128 & 20 & $12.8 \%$ & $8.9 \%$ \\
\hline & & Minimum & 9554 & 210 & 3 & 1 & $-5.7 \%$ & $-1.8 \%$ \\
\hline & & Maximum & $9,890,000$ & 15,130 & 765 & 104 & $218.9 \%$ & $157.0 \%$ \\
\hline
\end{tabular}


Table 3: Parameter Estimates and Regression Statistics, Production Function Estimate, CRS and VRS assumptions.

\begin{tabular}{|c|c|c|c|c|c|c|c|}
\hline & & CRS & & & VRS & & \\
\hline Description & Parameter & Estimate & $\mathrm{T}$ & $\mathrm{p}$ & Estimate & $\mathrm{T}$ & $\mathrm{p}$ \\
\hline Constant & a & 7.342 & 4.382 & 0.000 & 0.782 & 0.310 & 0.757 \\
\hline Berth Length & $b_{b}$ & 0.775 & 1.005 & 0.315 & 2.259 & 2.294 & 0.022 \\
\hline Total Area & $b_{a}$ & 1.107 & 2.831 & 0.005 & 1.475 & 3.076 & 0.002 \\
\hline Total Equipment & $b_{e}$ & -0.881 & -1.841 & 0.066 & -0.860 & -1.687 & 0.092 \\
\hline Time & $g_{t}$ & 0.188 & 2.949 & 0.003 & 0.064 & 0.901 & 0.368 \\
\hline Berth Length Squared & $c_{b}$ & -0.134 & -0.753 & 0.451 & -0.308 & -1.549 & 0.121 \\
\hline Total Area Squared & $\mathrm{C}_{\mathrm{a}}$ & -0.402 & -6.149 & 0.000 & -0.267 & -3.988 & 0.000 \\
\hline Total Equipment Squared & $\mathrm{C}_{\mathrm{e}}$ & -0.506 & -7.115 & 0.000 & -0.610 & -9.472 & 0.000 \\
\hline Time Squared & $g_{\mathrm{tt}}$ & -0.007 & -1.844 & 0.065 & -0.006 & -1.821 & 0.069 \\
\hline Berth Length/Total Area & $c_{b a}$ & 0.015 & 0.166 & 0.868 & -0.070 & -0.691 & 0.489 \\
\hline Berth Length/Total Equipment & $c_{b e}$ & 0.119 & 1.082 & 0.279 & 0.235 & 2.173 & 0.030 \\
\hline Total Area/Total Equipment & $\mathrm{Cae}_{\mathrm{a}}$ & 0.387 & 6.853 & 0.000 & 0.244 & 4.695 & 0.000 \\
\hline Time/Berth Length & $h_{\text {te }}$ & -0.029 & -2.154 & 0.031 & -0.009 & -0.663 & 0.507 \\
\hline Time/Total Area & $h_{\mathrm{ta}}$ & 0.008 & 0.818 & 0.414 & 0.005 & 0.568 & 0.570 \\
\hline \multirow[t]{7}{*}{ Time/Total Equipment } & $h_{\text {te }}$ & 0.021 & 2.050 & 0.040 & 0.014 & 1.480 & 0.139 \\
\hline & $\bar{R}^{2}$ & 0.8729 & & & 0.9023 & & \\
\hline & $\mathrm{F}$ & 579.46 & & & 501.09 & & \\
\hline & $\mathrm{p}:$ & 0.000 & & & 0.000 & & \\
\hline & $\log$ & & & & - & & \\
\hline & Likelihood & 516.977 & & & 414.576 & & \\
\hline & $\mathrm{p}:$ & 0.000 & & & 0.000 & & \\
\hline
\end{tabular}


Table 4: DEA CRS and COLS Translog CRS Full Panel, Container Ports Technical Efficiencies, 2001 to 2011

\begin{tabular}{|l|r|r|r|r|r|r|r|r|r|r|r|r|}
\hline Year & 2001 & 2002 & 2003 & 2004 & 2005 & 2006 & 2007 & 2008 & 2009 & 2010 & 2011 & $\begin{array}{l}\text { Period } \\
\text { Mean }\end{array}$ \\
\hline DEA & & & & & & & & & & & \\
Whole Sample & $54.7 \%$ & $54.7 \%$ & $52.2 \%$ & $57.4 \%$ & $59.4 \%$ & $56.7 \%$ & $60.4 \%$ & $58.3 \%$ & $55.3 \%$ & $54.7 \%$ & $53.7 \%$ & $56.1 \%$ \\
Top Ports & $60.0 \%$ & $59.5 \%$ & $55.2 \%$ & $61.7 \%$ & $63.5 \%$ & $60.5 \%$ & $64.5 \%$ & $61.9 \%$ & $58.6 \%$ & $58.6 \%$ & $57.8 \%$ & $60.2 \%$ \\
Caribbean & $40.3 \%$ & $42.0 \%$ & $40.9 \%$ & $45.2 \%$ & $47.4 \%$ & $45.0 \%$ & $48.8 \%$ & $48.8 \%$ & $44.8 \%$ & $41.3 \%$ & $40.4 \%$ & $44.1 \%$ \\
OSIDS & $23.7 \%$ & $25.6 \%$ & $31.1 \%$ & $25.0 \%$ & $26.4 \%$ & $28.4 \%$ & $33.6 \%$ & $31.2 \%$ & $33.8 \%$ & $31.4 \%$ & $32.1 \%$ & $29.3 \%$ \\
\hline & & & & & & & & & & & & \\
COLS & & & & & & & & & & & \\
Whole Sample & $43 \%$ & $40.4 \%$ & $39.3 \%$ & $40.2 \%$ & $39.9 \%$ & $41.6 \%$ & $42.4 \%$ & $41.9 \%$ & $38.2 \%$ & $42.4 \%$ & $41.9 \%$ & $41.0 \%$ \\
Top Ports & $46.6 \%$ & $42.7 \%$ & $41.0 \%$ & $41.8 \%$ & $41.5 \%$ & $43.2 \%$ & $43.8 \%$ & $43.1 \%$ & $39.3 \%$ & $43.9 \%$ & $44.3 \%$ & $42.8 \%$ \\
Caribbean & $32.6 \%$ & $32.6 \%$ & $31.9 \%$ & $33.6 \%$ & $33.1 \%$ & $35.0 \%$ & $36.7 \%$ & $37.0 \%$ & $32.7 \%$ & $33.2 \%$ & $33.1 \%$ & $33.8 \%$ \\
OSIDS & $20.3 \%$ & $19.8 \%$ & $22.1 \%$ & $16.9 \%$ & $16.8 \%$ & $19.6 \%$ & $22.2 \%$ & $22.0 \%$ & $24.0 \%$ & $26.0 \%$ & $27.1 \%$ & $21.5 \%$ \\
\hline
\end{tabular}


Table 5: Total factor productivity, efficiency and technical change, whole sample, DEA and COLS estimates

\begin{tabular}{|l|l|l|l|l|l|l|}
\hline \multirow{2}{*}{ Year } & DEA & \multicolumn{1}{l|}{ COLS } \\
\cline { 2 - 6 } & EC & TC & TFP & EC & TC & TFP \\
\hline 2002 & 1.023 & 0.993 & 1.016 & 0.953 & 1.051 & 1.001 \\
2003 & 0.961 & 1.070 & 1.029 & 0.978 & 1.044 & 1.021 \\
2004 & 1.095 & 0.979 & 1.071 & 1.017 & 1.036 & 1.054 \\
2005 & 1.046 & 0.986 & 1.032 & 1.005 & 1.029 & 1.035 \\
2006 & 0.953 & 1.114 & 1.061 & 1.036 & 1.022 & 1.059 \\
2007 & 1.072 & 0.978 & 1.049 & 1.027 & 1.016 & 1.043 \\
2008 & 0.955 & 1.042 & 0.995 & 0.979 & 1.009 & 0.987 \\
2009 & 0.946 & 0.960 & 0.908 & 0.910 & 1.001 & 0.911 \\
2010 & 0.973 & 1.113 & 1.083 & 1.089 & 0.994 & 1.083 \\
2011 & 0.964 & 1.024 & 0.987 & 0.978 & 0.987 & 0.965 \\
\hline Mean & 0.997 & 1.025 & 1.022 & 0.996 & 1.019 & 1.015 \\
Pre Crisis & 1.024 & 1.019 & 1.043 & 1.002 & 1.033 & 1.035 \\
Post Crisis & 0.959 & 1.033 & 0.991 & 0.987 & 0.998 & 0.985 \\
\hline
\end{tabular}


Table 6: Total factor productivity, efficiency and technical change, by comparator group, whole sample, DEA and COLS estimates

\begin{tabular}{|l|r|r|r|r|r|r|}
\hline & \multicolumn{1}{l|}{ DEA } & \multicolumn{1}{l|}{ COLS } \\
\hline & \multicolumn{1}{l|}{ TC } & \multicolumn{1}{l|}{ EC } & \multicolumn{1}{l|}{ TFP } & \multicolumn{1}{l|}{ TC } & \multicolumn{1}{l|}{ EC } & \multicolumn{1}{l|}{ TFP } \\
\cline { 2 - 8 } Whole Sample & 1.025 & 0.997 & 1.022 & 1.019 & 0.996 & 1.015 \\
Top Ports & 1.026 & 0.995 & 1.020 & 1.021 & 0.994 & 1.015 \\
Caribbean & 1.025 & 1.007 & 1.032 & 1.017 & 1.008 & 1.024 \\
OSIDS & 1.011 & 1.017 & 1.028 & 1.010 & 1.015 & 1.025 \\
\hline Pre Crisis (2001 - 2007) & & & & & & \\
Whole Sample & 1.019 & 1.024 & 1.043 & 1.033 & 1.002 & 1.035 \\
Top Ports & 1.021 & 1.015 & 1.036 & 1.035 & 0.994 & 1.029 \\
Caribbean & 1.019 & 1.049 & 1.069 & 1.032 & 1.029 & 1.061 \\
OSIDS & 0.994 & 1.050 & 1.043 & 1.024 & 1.015 & 1.039 \\
\hline
\end{tabular}


Table 7: Container Ports Included in the Study

\begin{tabular}{|c|c|c|c|}
\hline \multicolumn{4}{|l|}{ TOP PORTS } \\
\hline Port & Country & Port & Country \\
\hline Buenos Aires & Argentina & Maarsaxlokk & Malta \\
\hline Melbourne & Australia & Manila & Phillipines \\
\hline Sydney & Australia & Leixoes & Portugal \\
\hline Antwerp & Belgium & Lisbon & Portugal \\
\hline Zeebrugge & Belgium & St. Petersburg & Russia \\
\hline Montreal & Canada & Dammam & Saudi Arabia \\
\hline Vancouver & Canada & Jeddah & Saudi Arabia \\
\hline Fuzhou & China & Gwangyang & South Korea \\
\hline Yantai & China & Barcelona & Spain \\
\hline Damietta & Egypt & Bilbao & Spain \\
\hline Dunkirk & France & Gothenburg & Sweden \\
\hline Le Havre & France & Taichung & Taiwan \\
\hline Bremerhaven & Germany & Bangkok & Thailand \\
\hline Duisburg & Germany & Ambarli & Turkey \\
\hline Hamburg & Germany & Felixstowe & UK \\
\hline Piraeus & Greece & Charleston & US \\
\hline Tuticorin & India & Honolulu & US \\
\hline Haifa & Israel & New York/Jersey & US \\
\hline Genoa & Italy & Oakland & US \\
\hline La Spezia & Italy & Savannah & US \\
\hline Yokohama & Japan & Seattle & US \\
\hline Osaka & Japan & Tacoma & US \\
\hline Kobe & Japan & Norfolk Virginia & US \\
\hline Nagoya & Japan & Ho Chi Minh City & Vietnam \\
\hline Penang & Malaysia & & \\
\hline \multicolumn{4}{|c|}{ CARIBBEAN SIDS PORTS } \\
\hline Port & Country & Port & Country \\
\hline St. John & Antigua \& Barbuda & Kingston & Jamaica \\
\hline Freeport & Bahamas & Willemstad & NL Antilles \\
\hline Bridgetown & Barbados & Castries & St. Lucia \\
\hline Rio Haina & Dominican Rep. & Vieux Fort & St. Lucia \\
\hline Caucedo & Dominican Rep. & Point Lisas & Trinidad \& Tobago \\
\hline Pointe-Pitre & Guadeloupe & Port of Spain & Trinidad \& Tobago \\
\hline \multicolumn{4}{|c|}{ OTHER SIDS PORTS } \\
\hline Port & Country & Port & Country \\
\hline Papeete & French Polynesia & Port Louis & Mauritius \\
\hline Apra & Guam & Noumea & New Caledonia \\
\hline
\end{tabular}


Table 8. Container port technical efficiency and productivity studies

\begin{tabular}{|c|c|c|c|c|}
\hline Author & Data Set & Year Examined & Input & Output \\
\hline Tongzon (2001) & $\begin{array}{l}\text { Australian and other } \\
\text { international }\end{array}$ & 1996 & $\begin{array}{l}\text { No. cranes, berths, tugs, } \\
\text { labor, delay time, terminal } \\
\text { area }\end{array}$ & $\begin{array}{l}\text { TEU throughput, } \\
\text { Ship working rate }\end{array}$ \\
\hline $\begin{array}{l}\text { Valentine and } \\
\text { Gray (2001) }\end{array}$ & 31 top & 1998 & $\begin{array}{l}\text { Total berth length, av. } \\
\text { berth length }\end{array}$ & $\begin{array}{l}\text { TEU throughput, } \\
\text { Total tons }\end{array}$ \\
\hline Itoh (2002) & 8 Japanese & 1990-1999 & $\begin{array}{l}\text { Terminal area } \\
\text { No. of berths } \\
\text { No. Gantry cranes } \\
\text { No. of workers }\end{array}$ & TEU throughput \\
\hline $\begin{array}{l}\text { Barros and } \\
\text { Athanassiou, } \\
(2004)\end{array}$ & $\begin{array}{l}6 \text { Portuguese and } \\
\text { Greek }\end{array}$ & $1998-2000$ & Labour, capital & $\begin{array}{l}\text { TEU throughput, } \\
\text { cargo }\end{array}$ \\
\hline $\begin{array}{l}\begin{array}{l}\text { Turner et al } \\
(2004)\end{array} \\
\end{array}$ & 26 North American & 1984-1997 & $\begin{array}{l}\text { Quay length, terminal } \\
\text { area, No. cranes }\end{array}$ & TEU throughput \\
\hline $\begin{array}{l}\text { Cullinane et al, } \\
\text { (2005) }\end{array}$ & Top 30 & 1999 & $\begin{array}{l}\text { No. Gantry cranes No. } \\
\text { Yard cranes } \\
\text { No. Straddle carriers } \\
\text { Quay length } \\
\text { Terminal area }\end{array}$ & TEU throughput \\
\hline $\begin{array}{l}\text { Cullinane \& } \\
\text { Wang (2006) }\end{array}$ & Top 30 & $\begin{array}{l}2001, \\
1992-1999\end{array}$ & $\begin{array}{l}\text { No. Gantry cranes } \\
\text { No. of Yard cranes } \\
\text { No. of Straddle carriers } \\
\text { Quay length } \\
\text { Terminal area }\end{array}$ & TEU throughput \\
\hline $\begin{array}{l}\text { Wang \& } \\
\text { Cullinane (2006) }\end{array}$ & European & 2003 & $\begin{array}{l}\text { Terminal length, area, } \\
\text { equipment costs }\end{array}$ & TEU throughput \\
\hline $\begin{array}{l}\text { Hung, Lu \& } \\
\text { Wang (2010) }\end{array}$ & 31 top Asian- Pacific & 2007 & $\begin{array}{l}\text { Terminal length, area, No. } \\
\text { berths, No. gantry cranes }\end{array}$ & TEU throughput \\
\hline $\begin{array}{l}\text { Wu \& Goh } \\
(2010)\end{array}$ & Top 21 BRIC & 2005 & $\begin{array}{l}\text { No. of Quayside cranes } \\
\text { No. of Yard cranes } \\
\text { No. of Straddle carriers } \\
\text { Quay Length }\end{array}$ & TEU throughput \\
\hline $\begin{array}{l}\text { Wanke et al } \\
(2011)\end{array}$ & 25 Brazilian & 2009 & $\begin{array}{l}\text { No. of berths, Terminal } \\
\text { Area, Parking lot (no. of } \\
\text { trucks) }\end{array}$ & $\begin{array}{l}\text { Throughput tons, } \\
\text { Loaded } \\
\text { shipments }\end{array}$ \\
\hline $\begin{array}{l}\text { Bo \& Wang } \\
(2012)\end{array}$ & $\begin{array}{l}31 \text { Major Chinese } \\
\text { and Korean }\end{array}$ & 2010 & $\begin{array}{l}\text { Yard area per berth, No. } \\
\text { quay cranes, No. yard } \\
\text { cranes, No. yard } \\
\text { tractor per berth, Berth } \\
\text { depth and length }\end{array}$ & TEU throughput \\
\hline $\begin{array}{l}\text { Niavis \& } \\
\text { Tsekeris (2012) }\end{array}$ & $\begin{array}{l}30 \text { South-Eastern } \\
\text { European }\end{array}$ & 2008 & $\begin{array}{l}\text { No. of berths, berth } \\
\text { length, No. of cranes }\end{array}$ & TEU throughput \\
\hline $\begin{array}{l}\text { Dan, Weixin, \& } \\
\text { Feng (2013) }\end{array}$ & 42 coastal China & 2010 & $\begin{array}{l}\text { Terminal length, handling, } \\
\text { equipment, labour } \\
\text { quantity }\end{array}$ & TEU throughput \\
\hline
\end{tabular}




\begin{tabular}{|c|c|c|c|c|}
\hline $\begin{array}{l}\text { Schoyen } \quad \& \\
\text { Odeck (2013) }\end{array}$ & 24 Norwegian/UK & $2002-2008$ & $\begin{array}{l}\text { Berth length Terminal } \\
\text { area, No. yard cranes, } \\
\text { straddle carriers }\end{array}$ & $\begin{array}{l}\text { TEU throughput, } \\
\text { container } \\
\text { handling trucks }\end{array}$ \\
\hline $\begin{array}{l}\text { Wilmsmeier et } \\
\text { al (2013) }\end{array}$ & 20 LAC/Spain & $2005-2011$ & $\begin{array}{l}\text { Terminal area, ship to } \\
\text { shore crane capacity, } \\
\text { labour }\end{array}$ & TEU throughput, \\
\hline Ding et al (2015) & 16 Coastal China & $2008-2012$ & $\begin{array}{l}\text { Berth length } \\
\text { Handling Equipment } \\
\text { Total Staff }\end{array}$ & TEU throughput \\
\hline $\begin{array}{l}\text { Serebrisky et al } \\
(2016)\end{array}$ & 63 LAC & $\begin{array}{l}\text { 1999-2009, } \\
2009\end{array}$ & $\begin{array}{l}\text { Berth length } \\
\text { Terminal area } \\
\text { Ownership structure } \\
\text { Port size }\end{array}$ & TEU throughput \\
\hline $\begin{array}{l}\text { Suarez-Aleman } \\
\text { et al (2016) }\end{array}$ & $\begin{array}{l}203 \text { Developing } \\
\text { Countries ports }\end{array}$ & $2000-2010$ & $\begin{array}{l}\text { Terminal area, No. mobile } \\
\text { cranes, No. gantry cranes, } \\
\text { berth length, exogenous } \\
\text { variables }\end{array}$ & TEU throughput, \\
\hline
\end{tabular}

